\title{
Diagnostic Validity of Cone Beam Computed Tomography Radiography in Detection of Dental Caries \\ Ghaida Abbas Katib ${ }^{1}$ and Reem Mazen Alfuraih ${ }^{2}$ \\ (1) Ibn Sina National Collage, General Dentist in Primary Health Care, (2) Alfarabi Colleges, Saudi \\ Arabia
}

\begin{abstract}
Introduction: Comparison between tomography and one or more digital intra-oral systems have been conducted with histological sectioning of the offending teeth as gold standard for comparison. The findings in the literature are contradicting, since some studies showed superiority of tomography. This systematic review aimed at evaluating the evidence in relation to the diagnostic accuracy of cone beam computed tomography compared to the digital and film-based intra-oral radiography.

Methods: An electronic search was conducted on Medline Plus, PubMed, Science Direct, and Wiley databases. All articles published in English language up to October 2017 were eligible to be included in this review. Search on different search engines and different database websites including hand search revealed 496 articles. After reading titles and abstracts, irrelevant and duplicated articles 459 were excluded. The resulting articles were read carefully for comparison of accuracy between CBCT and other intra-oral radiographic systems and the references lists of the resulting articles were screened for additional studies.

Results: A total of 22 articles, available according to the inclusion criteria, were included in this systematic review. Most of the studies (13 articles) were conducted on premolars and molars while, 5 studies were conducted on molars, one study was conducted on premolars, one study was on incisors, and two studies did not report the type of teeth used. The majority of the studies (21articles) were laboratory experiments (in-vitro) while, only one study was in-vivo. The sample size for the studies (number of teeth) ranged from 30 to 257 teeth.

Conclusions: CBCT has similar diagnostic accuracy as other intra-oral systems for diagnosing dental caries. CBCT is not recommended for caries diagnosis unless the CBCT was undertaken for any other procedures where the dental caries should be included in the final report.
\end{abstract}

Keywords: Tomography, Radiography, Dental caries, Accuracy, Intraoral

\section{INTRODUCTION}

Dental caries is considered one of the most chronic diseases worldwide, causing demineralization of dental hard tissues. This lesion will progress under the microbial biofilm unless the biofilm is totally removed ${ }^{(1)}$. Various classification systems have been reported to facilitate the diagnosis of carious lesions by clinical visual examination. This method is reliable and possible for visible surfaces such as occlusal, buccal or lingual surfaces whereas its ability is limited for diagnosis of the carious lesions in the proximal surfaces. Less than $50 \%$ of cavitated lesions on the proximal surfaces can be detected by clinical visual examination (2).

Digital radiography is used widely in dental practice and there is considerable increase in the number of clinics which tend to use it. It has shown several advantages over the conventional film images. Display of the digital images has been facilitated by providing software programs working on conventional PC monitors (3). These programs have many different tools for adjusting and optimizing the images for different diagnostic tasks. The diagnostic performance of digital radiography has been widely studied in laboratory experiments. Some studies reported that digital radiography have more accuracy than film radiography in detecting caries while some other studies reported that digitized films have the same accuracy of charge-coupled device (CCD) system. In contrast, paper-print images of CCD system have less accuracy than film images ${ }^{(3)}$. One drawback of the laboratory experiments is that the mechanically created lesions have the opportunity to be detected by radiography more than those created naturally ${ }^{(3)}$. This will reflect negatively on the results of these types of studies and should be taken with precautions. Three-Dimensional radiographic modality is or cone beam computed tomography (CBCT) is a new radiographic modality in the dental clinic. It is a volumetricbased image where the tomographic sections are obtained in given resolutions which then are 
joined together to form a cubic pixel. Comparison between CBCT and one or more digital intra-oral systems has been conducted with histological sectioning of the offending teeth as gold standard for comparison. It was reported in most of these studies that CBCT has no superior accuracy than other digital intraoral systems for detection of the carious lesions on the proximal surfaces. On the other hand, some other authors have reported that CBCT has slightly higher accuracy than other intraoral images in detecting the depth of carious lesion. This systematic review aimed at evaluating the evidence in relation to the diagnostic accuracy of CBCT compared to the digital and film-based intra-oral radiography.

\section{METHODS}

An electronic search was conducted on Medline Plus, PubMed, Science Direct, and Wiley databases. Keywords used for this research included; dental caries, dental decay, cone beam computed tomography, CBCT scan, periapical radiography, bitewing radiography, intraoral radiography, panoramic radiography, and accuracy. The flow of the information through the different stages of the systematic review (identification, screening, eligibility, inclusion) was demonstrated in Figure (1). All articles published in English language up to October 2017 were eligible to be included in this review. Search on different search engines and different database websites including hand search on the public search engine (Google Scholar) revealed 496 articles. After reading titles and abstracts, irrelevant and duplicated articles 459 were excluded. The resulting articles were read carefully for comparison of accuracy between CBCT and other intra-oral radiographic systems and the references lists of the resulting articles were screened for additional studies. Review articles and articles without CBCT comparison were excluded. Therefore, the included articles for this review were 22 articles. Extraction of the data in relation to the required information was ensured by two reviewers. The data extraction form included: type of the study, number of teeth, type and location of caries, type of CBCT used, type of other intra-oral radiography, accuracy of CBCT, accuracy of the compared techniques, and conclusion of the study.
A total of 22 articles, available according to the inclusion criteria, were included in this systematic review (Table 1). Most of the studies (13 articles) were conducted on premolars and molars while, 5 studies were conducted on molars, one study was conducted on premolars, one study was on incisors, and two studies did not report the type of teeth used. The majority of the studies (21articles) were laboratory experiments (in-vitro) while, only one study was in-vivo. The sample size for the studies (number of teeth) ranged from 30 to 257 teeth. However, some studies performed the diagnosis on more than one surface of the teeth. Five studies aimed to test the accuracy of CBCT in detecting the carious lesions on the occlusal surfaces while, eight studies compared the accuracy in detecting the proximal lesions. Three studies were conducted to compare the accuracy in detecting mechanically-created secondary lesions under restorations (amalgam and composite). Four studies were conducted on cavitated carious lesions. Three studies were conducted on carious lesions on both occlusal and proximal surfaces. Different brands of CBCT and other intra-oral radiographies were used. Newtom $3 \mathrm{G}$ was used in 8 studies, Accuitomo was used in six studies, Promax and Kodak 9000 3D were used in four studies, equally. ILUMA was used in three studies while, Limited CBCT, DCT Pro, and Sirona were used in two studies, equally. Pax 500 ECT, I-CAT, and Cranex were used in one study, equally. For the compared techniques, conventional film-based system was used in 14 studies, PSP system was used in 13 studies, CCD system was used in 3 studies while, Sirona, Vitascan, RVG, and K 9000 were used in one study equally. Diagnostic accuracy of CBCT and the other intra-oral techniques were reported as area under the receiver operating characteristic (ROC) curve (Az) in most of the studies. Some other studies reported the diagnostic accuracy as Kappa test between the observers' opinions. The accuracy of the different techniques varied considerably among the different studies. In general, accuracy of CBCT ranged from $39 \%$ to $99 \%$; most of them were between $50 \%$ and $70 \%$ while, accuracy of the compared techniques ranged from $34 \%$ to 95\%; most of them were between $50 \%$ and $60 \%$.

\section{RESULTS}


Figure (1): Flow diagram of the included studies in the systematic review

Table (1): The findings of the included studies regarding accuracy of dental tomography

\begin{tabular}{|c|c|c|c|c|c|c|}
\hline Author(s) & $\begin{array}{l}\text { Sample } \\
\text { size }\end{array}$ & $\begin{array}{c}\text { Type of } \\
\text { teeth } \\
\text { assessed }\end{array}$ & $\begin{array}{l}\text { Type of dental } \\
\text { caries assessed }\end{array}$ & $\begin{array}{l}\text { Technique of } \\
\text { CBCT }\end{array}$ & $\begin{array}{l}\text { Compared } \\
\text { techniques }\end{array}$ & Conclusion \\
\hline $\begin{array}{l}\text { Charuakkr } \\
\text { a et al. }{ }^{(4)}\end{array}$ & 120 & $\begin{array}{l}\text { Premolars } \\
\text { and molars }\end{array}$ & $\begin{array}{l}\text { Mechanically } \\
\text { created } \\
\text { secondary } \\
\text { caries }\end{array}$ & $\begin{array}{l}\text { - Pax-500 ECT } \\
\text { - Promax 3D }\end{array}$ & Conventional & $\begin{array}{l}\text { CBCT images were better in } \\
\text { detection of secondary caries. }\end{array}$ \\
\hline $\begin{array}{l}\text { Wenzel et } \\
\text { al. }{ }^{(5)}\end{array}$ & 257 & $\begin{array}{l}\text { Premolars } \\
\text { and molars }\end{array}$ & $\begin{array}{l}\text { Cavitated } \\
\text { proximal caries }\end{array}$ & Accuitomo 3D & $\begin{array}{l}\text { - PSP } \\
\text { - CMOS } \\
\text { sensor }\end{array}$ & $\begin{array}{l}\text { CBCT was more accurate in } \\
\text { detection of cavitated proximal } \\
\text { surface. }\end{array}$ \\
\hline $\begin{array}{l}\text { Krzyzostan } \\
\text { et al. }{ }^{(6)}\end{array}$ & 135 & $\begin{array}{l}\text { Premolars } \\
\text { and molars }\end{array}$ & $\begin{array}{l}\text { Non-cavitated } \\
\text { occlusal and } \\
\text { proximal caries }\end{array}$ & Newtom 3G & $\begin{array}{l}\text { - } \\
\text { Conventional } \\
\text { - PSP }\end{array}$ & $\begin{array}{l}\text { - CBCT was significantly worse than } \\
\text { other radiographic techniques. } \\
\text { - The accuracy of all systems still } \\
\text { low. }\end{array}$ \\
\hline $\begin{array}{l}\text { Zhang et } \\
\text { al. }{ }^{(7)}\end{array}$ & 39 & & $\begin{array}{l}\text { Non-cavitated } \\
\text { proximal caries }\end{array}$ & $\begin{array}{l}\text { - Promax 3D } \\
\text { - Kodak } 9000 \\
\text { 3D }\end{array}$ & $\begin{array}{l}\text { - } \\
\text { Conventional } \\
\text { - PSP }\end{array}$ & $\begin{array}{l}\text { - CBCT was similar to the other } \\
\text { radiographic techniques. } \\
\text { - All systems are not clinically } \\
\text { accepted. } \\
\text { - CBCT should not be used for } \\
\text { caries diagnosis. }\end{array}$ \\
\hline $\begin{array}{l}\text { Young et } \\
\text { al. }^{(8)}\end{array}$ & 192 & $\begin{array}{l}\text { Premolars } \\
\text { and molars }\end{array}$ & $\begin{array}{l}\text { Occlusal and } \\
\text { proximal caries }\end{array}$ & Accuitomo 3D & Conventional & $\begin{array}{l}\text { CBCT was better in detecting } \\
\text { proximal caries extending to dentin } \\
\text { but not occlusal. }\end{array}$ \\
\hline $\begin{array}{l}\text { Ramezani } \\
\text { et al. }{ }^{(9)}\end{array}$ & 88 & Molars & Occlusal & Newtom 3G & PSP & $\begin{array}{l}\text { - CBCT was slightly better but with } \\
\text { no significant difference. } \\
\text { - All systems still under the gold } \\
\text { standards. }\end{array}$ \\
\hline $\begin{array}{l}\text { Akdeniz et } \\
\text { al. }{ }^{(10)}\end{array}$ & 41 & $\begin{array}{l}\text { Premolars } \\
\text { and molars }\end{array}$ & $\begin{array}{l}\text { Mechanically } \\
\text { created } \\
\text { proximal caries }\end{array}$ & $\begin{array}{l}\text { - Limited CBCT } \\
\text { - Accuitomo 3D }\end{array}$ & $\begin{array}{l}\text { - } \\
\text { Conventional } \\
\text { - PSP }\end{array}$ & $\begin{array}{l}\text { Limited CBCT was better than other } \\
\text { techniques in detecting the depth of } \\
\text { small proximal caries. }\end{array}$ \\
\hline $\begin{array}{l}\text { Kayipmaz } \\
\text { et al. }{ }^{(11)}\end{array}$ & 72 & $\begin{array}{l}\text { Premolars } \\
\text { and molars }\end{array}$ & $\begin{array}{l}\text { Occlusal and } \\
\text { proximal caries }\end{array}$ & Kodak 9000 3D & $\begin{array}{l}\text { - } \\
\text { Conventional } \\
\text { - PSP }\end{array}$ & $\begin{array}{l}\text { - CBCT was better in detecting } \\
\text { occlusal caries. } \\
\text { - No significant differences were } \\
\text { found between all systems in } \\
\text { detecting proximal caries. }\end{array}$ \\
\hline $\begin{array}{l}\text { Sousa } \\
\text { Melo et al. } \\
\text { (12) }\end{array}$ & 30 & Molars & $\begin{array}{l}\text { Mechanically } \\
\text { created } \\
\text { proximal } \\
\text { recurrent caries } \\
\text { under amalgam } \\
\text { and composite } \\
\text { restorations }\end{array}$ & $\begin{array}{l}\text { - I-CAT02 } \\
\text { - I-CAT04 }\end{array}$ & $\begin{array}{l}\text { - Digora } \\
\text { - Vitascan } \\
\text { - RVG } 6100 \\
\text { - K } 9000\end{array}$ & $\begin{array}{l}\text { CBCT has similar effectiveness to } \\
\text { intraoral digital radiography in } \\
\text { detecting proximal caries under } \\
\text { restorations particularly composite } \\
\text { restorations. }\end{array}$ \\
\hline
\end{tabular}




\begin{tabular}{|c|c|c|c|c|c|c|}
\hline $\begin{array}{l}\text { Kasraei et } \\
\text { al. }{ }^{(13)}\end{array}$ & 45 & Molars & $\begin{array}{l}\text { Mechanically } \\
\text { created } \\
\text { proximal } \\
\text { recurrent caries } \\
\text { under } \\
\text { composite } \\
\text { restorations } \\
\end{array}$ & $\begin{array}{l}\text { - Cranex 3D } \\
\text { - Newtom 3G }\end{array}$ & $\begin{array}{l} \\
\text { Conventional } \\
\text { - PSP }\end{array}$ & $\begin{array}{l}\text { CBCT has higher diagnostic } \\
\text { accuracy than other techniques in } \\
\text { detecting secondary caries under } \\
\text { composite restorations. }\end{array}$ \\
\hline$\underset{(14)}{Q u}$ et al. & 39 & & $\begin{array}{l}\text { Non-cavitated } \\
\text { proximal caries }\end{array}$ & $\begin{array}{l}\text { - Newtom 3G } \\
\text { - Accuitomo 3D } \\
\text { - Kodak 9000 } \\
\text { 3D } \\
\text { - Promax 3D } \\
\text { - DCT PRO }\end{array}$ & & $\begin{array}{l}\text { No significant differences were } \\
\text { found between all systems in } \\
\text { detecting non-cavitated proximal } \\
\text { caries. }\end{array}$ \\
\hline $\begin{array}{l}\text { Cheng et } \\
\text { al. }{ }^{(15)}\end{array}$ & 45 & $\begin{array}{l}\text { Premolars } \\
\text { and molars }\end{array}$ & $\begin{array}{l}\text { Non-restored } \\
\text { proximal caries }\end{array}$ & $\begin{array}{l}\text { - Promax 3D } \\
\text { - DCT PRO } \\
\text { (with different } \\
\text { resolutions) }\end{array}$ & PSP & $\begin{array}{l}\text { - No significant differences were } \\
\text { found between CBCT and PSP. } \\
\text { - The spatial resolutions did not have } \\
\text { an impact on the accuracy of } \\
\text { detection of proximal caries. }\end{array}$ \\
\hline$\underset{(16)}{\text { Safi et al. }}$ & 42 & $\begin{array}{l}\text { Premolars } \\
\text { and molars }\end{array}$ & $\begin{array}{l}\text { Non-cavitated } \\
\text { interproximal } \\
\text { caries }\end{array}$ & Newtom 3G & $\begin{array}{l} \\
\text { Conventional } \\
\text { - PSP }\end{array}$ & $\begin{array}{l}\text { - No significant differences were } \\
\text { found between all systems. } \\
\text { - CBCT is not recommended for } \\
\text { diagnosis of interproximal caries. }\end{array}$ \\
\hline $\begin{array}{l}\text { Krzyzostani } \\
\text { ak et al. }{ }^{\left({ }^{\prime}\right)}\end{array}$ & 135 & $\begin{array}{l}\text { Premolars } \\
\text { and molars }\end{array}$ & $\begin{array}{l}\text { Non-cavitated } \\
\text { occlusal caries }\end{array}$ & Newtom 3G & Conventional & $\begin{array}{l}\text { - No significant differences were } \\
\text { found between both systems. } \\
\text { - CBCT is not recommended for } \\
\text { diagnosis of occlusal caries. }\end{array}$ \\
\hline $\begin{array}{l}\text { Senel et al. } \\
(18)\end{array}$ & 138 & $\begin{array}{l}\text { Premolars } \\
\text { and molars }\end{array}$ & Proximal caries & ILUMA & $\begin{array}{l}- \\
\text { Conventional } \\
- \text { PSP } \\
- \text { CCD }\end{array}$ & $\begin{array}{l}\text { No significant differences were } \\
\text { found between all systems in } \\
\text { detecting proximal caries. }\end{array}$ \\
\hline $\begin{array}{l}\text { Tsuchida et } \\
\text { al. }{ }^{(19)}\end{array}$ & 50 & Premolars & Proximal caries & Accuitomo 3D & Conventional & $\begin{array}{l}\text { CBCT could not enhance the } \\
\text { accuracy in detecting the proximal } \\
\text { caries. }\end{array}$ \\
\hline $\begin{array}{l}\text { Valizadeh } \\
\text { et al. }{ }^{(20)}\end{array}$ & 84 & $\begin{array}{l}\text { Premolars } \\
\text { and molars }\end{array}$ & Proximal caries & Newtom 3G & Conventional & $\begin{array}{l}\text { CBCT did not enhance the accuracy } \\
\text { of detecting the proximal caries. }\end{array}$ \\
\hline $\begin{array}{l}\text { Rathore et } \\
\text { al. }{ }^{(21)}\end{array}$ & 60 & $\begin{array}{l}\text { Premolars } \\
\text { and molars }\end{array}$ & Occlusal caries & $\begin{array}{l}\text { Sirona Galileos } \\
\text { CBCT }\end{array}$ & PSP & $\begin{array}{l}\text { - No significant difference was } \\
\text { found between both systems. } \\
\text { - CBCT can not be used for the sole } \\
\text { purpose of detecting caries. }\end{array}$ \\
\hline $\begin{array}{l}\text { Kalathigal } \\
\text { et al. }{ }^{\left({ }^{2}\right)}\end{array}$ & 24 & $\begin{array}{l}\text { Premolars } \\
\text { and molars }\end{array}$ & Proximal caries & $\begin{array}{l}\text { Sirona local } \\
\text { CBCT }\end{array}$ & $\begin{array}{l}\text { Sirona digital } \\
\text { radiography }\end{array}$ & $\begin{array}{l}\text { - No significant difference was } \\
\text { found between both systems in } \\
\text { detecting proximal caries. } \\
\text { - CBCT was more accurate in } \\
\text { detecting the depth of caries. }\end{array}$ \\
\hline $\begin{array}{l}\text { Kamburogl } \\
\text { u et al. }{ }^{(23)}\end{array}$ & 21 & Molars & Occlusal caries & $\begin{array}{l}\text { - Accuitomo 3D } \\
\text { - ILUMA }\end{array}$ & $\begin{array}{l}- \text { Micro-CT } \\
- \text { CCD } \\
- \\
\text { Conventional }\end{array}$ & $\begin{array}{l}\text { - Micro-CT performed better in } \\
\text { detecting the depth of occlusal } \\
\text { caries. } \\
\text { - CBCT was similar to intraoral } \\
\text { radiographies. }\end{array}$ \\
\hline $\begin{array}{l}\text { Kamburogl } \\
\text { u et al. }{ }^{(24)}\end{array}$ & 130 & Molars & Occlusal caries & $\begin{array}{l}\text { ILUMA } \\
\text { (with different } \\
\text { resolutions) }\end{array}$ & $\mathrm{CCD}$ & $\begin{array}{l}\text { - CBCT performed better than CCD } \\
\text { in detection of caries. } \\
\text { - No effect was found for the } \\
\text { different resolutions in detection of } \\
\text { caries. }\end{array}$ \\
\hline $\begin{array}{l}\text { Sansare et } \\
\text { al. }{ }^{(25)}\end{array}$ & $\begin{array}{l}34 \\
\text { patients } \\
(79 \\
\text { teeth) }\end{array}$ & $\begin{array}{l}\text { Premolars } \\
\text { and molars }\end{array}$ & $\begin{array}{l}\text { Cavitated } \\
\text { proximal caries }\end{array}$ & Kodak 9000 3D & Conventional & $\begin{array}{l}\text { - CBCT was significantly more } \\
\text { accurate than conventional in } \\
\text { detecting proximal caries. } \\
\text { - Caries should be reported in CBCT } \\
\text { when this type of radiography has } \\
\text { been taken for another clinical } \\
\text { application. }\end{array}$ \\
\hline
\end{tabular}

\section{DISCUSSION}

Comparison between CBCT and other different types of intra-oral conventional or digital radiographies was based on the observers' opinions and histological examination of the 
carious lesions. Despite these criteria in comparison, the majority of studies (22 out of 23) were laboratory-based experiments. Only one in-vivo study conducted by Sansare et al . (26) in which the authors compared the diagnostic accuracy of CBCT and conventional film-based system among patient with carious lesions. Another on laboratory study (27) compared the diagnostic accuracy in detecting dental caries between five types of CBCT without any other intra-oral systems for comparison. Among the available studies, eight studies concluded that CBCT was better than other intra-oral techniques in detecting secondary caries or cavitated carious lesions. However, the study done by Sousa Melo et al. (28) aimed at comparing the diagnostic accuracy of the CBCT and other intra-oral techniques in detecting mechanically-created recurrent caries under amalgam and composites restorations. The results of the study revealed no significant differences between CBCT and other radiographic systems. However, the accuracy of CBCT in detecting carious lesions under composite restorations was higher compared to that accuracy in detecting carious lesions under amalgam. This might be related to the presence of metal (amalgam) in the area of radiation. In this study, however, no conventional filmbased system was used for comparison.

Krzyzostan et al. ${ }^{(29)}$ compared the diagnostic accuracy of the CBCT system using Newtom $3 \mathrm{G}$ with conventional and PSP systems. The results revealed that CBCT was significantly worse than other intra-oral techniques in detecting non-cavitated occlusal and proximal caries. This is the only study which concluded that CBCT was worse with significant level. This might attributed to the type of the carious lesions as the non-cavitated lesions were diagnosed which seem to be difficult to appear clearly in the CBCT radiographs. Another two studies were carried out by Cheng et al. ${ }^{(30)}$ and Kamburoglu et al. ${ }^{(31)}$ in which they compared the effect of different resolutions of CBCT radiography on the accuracy of detecting the carious lesions. Both studies concluded that the difference in resolution of CBCT did not have an impact on the accuracy of detecting the carious lesions. About half of the studies reported that the diagnostic accuracy of CBCT was similar to the other intra-oral techniques with no significant difference.

It can be noted that no consensus was achieved among the studies regarding the diagnostic accuracy of CBCT which might be related to the use of different brands of CBCT systems, different fields of view, and the variations in the observers' opinions regarding their scores in diagnosing the carious lesions.

\section{CONCLUSION}

From this systematic review it was concluded that CBCT has nearly the same diagnostic accuracy as other intra-oral systems for diagnosing dental caries. CBCT is not recommended for caries diagnosis unless the CBCT was undertaken for any other procedures where the dental caries should be included in the final report.

\section{CONFLICT OF INTERESTS}

No financial sponsoring was received and no conflicts of interests.

\section{REFERENCES}

1.Selwitz RH, Ismail AI, Pitts NB (2007): Dental caries. Lancet, 369(9555):5159.

2.Wenzel A, Larsen M, Feierskov O (1991): Detection of occlusal caries without cavitation by visual inspection, film radiographs, xeroradiographs, and digitized radiographs. Caries Res., 25(5):365-371.

3.Kang BC, Farman AG, Scarfe WC, Goldsmith LJ (1996): Observer differentiation of proximal enamel mechanical defects versus natural proximal dental caries with computed dental radiography. Oral Surg Oral Med Oral Pathol Oral Radiol Endod., 82(4):459-465.

4.Charuakkra A, Prapayasatok S, Janhom A, Pongsiriwet S, Verochana $K$, Mahasantipiya P (2011): Diagnostic performance of cone-beam computed tomography on detection of mechanically-created artificial secondary caries. Imaging Sci Dent., 41(4):143-150.

5.Wenzel A, Hirsch E, Christensen J, Matzen LH, Scaf G, Frydenberg M (2013): Detection of cavitated approximal surfaces using cone beam $\mathrm{CT}$ and intraoral receptors. Dentomaxillofacial Radiol., 42(1):39458105-39458105.

6.Krzyżostaniak J, Kulczyk T, Czarnecka B, Surdacka A (2015): A comparative study of the diagnostic accuracy of cone beam computed tomography and intraoral radiographic modalities for 
the detection of noncavitated caries. Clin Oral Investig., 19(3):667-672.

7.Zhang Z-l, Qu X-m, Li G, Zhang Z-y, Ma X-c (2011): The detection accuracies for proximal caries by cone-beam computerized tomography, film, and phosphor plates. Oral Surg Oral Med Oral Pathol Oral Radiol Endod., 111(1):103-108.

8.Young S, Lee J, Hodges R, Chang T, Elashoff D, White S (2009): A comparative study of high-resolution cone beam computed tomography and charge-coupled device sensors for detecting caries. Dentomaxillofacial Radiol., 38(7):445-451.

9.Ramezani L, Salemi F, Shokri A, Sichani HF, Mirzayi M, Bagheri M (2016): A comparative study of the diagnostic accuracy of cone beam computed tomography and phosphor storage plate for detection of noncavitated occlusal caries Analiza porównawcza wartości diagnostycznej tomografii stożkowej i radiografii cyfrowej w wykrywaniu próchnicy początkowej na powierzchniach żujących. Dent Med Problem, 53(2):186-192.

10.Akdeniz BG, Gröndahl H-G, Magnusson B (2006): Accuracy of proximal caries depth measurements: comparison between limited cone beam computed tomography, storage phosphor and film radiography. Caries Res., 40(3):202207.

11.Kayipmaz S, Sezgin ÖS, Saricaoğlu ST, Çan G (2011): An in vitro comparison of diagnostic abilities of conventional radiography, storage phosphor, and cone beam computed tomography to determine occlusal and approximal caries. Eur J Radiol., 80(2):478-482.

12. Melo SLS, Belem MDF, Prieto LT, Tabchoury CPM, Haiter-Neto F (2017): Comparison of cone beam computed tomography and digital intraoral radiography performance in the detection of artificially induced recurrent caries-like lesions. Oral Surg Oral Med Oral Pathol Oral Radiol Endod., 124(3):306-314.

13.Kasraei S, Shokri A, Poorolajal J, Khajeh S, Rahmani H (2017): Comparison of cone-beam computed tomography and intraoral radiography in detection of recurrent caries under composite restorations. Braz Dent J., 28(1):85-91.

14.Qu X, Li G, Zhang Z, Ma X (2011): Detection accuracy of in vitro approximal caries by cone beam computed tomography images. Eur $\mathbf{J}$ Radiol., 79(2):e24-e27.

15.Cheng J-G, Zhang Z-L, Wang X-Y, Zhang Z-Y, Ma X-C, Li G (2012): Detection accuracy of proximal caries by phosphor plate and cone-beam computerized tomography images scanned with different resolutions. Clin Oral Investig, 16(4):1015-1021.

16.Safi Y, Mahmoudi NS, Aghdasi M, Manouchehri ME, Rahimian R, Valizadeh $S$ et al. (2015): Diagnostic accuracy of Cone Beam Computed Tomography, conventional and digital radiographs in detecting interproximal caries. J Med Life, 8(3):77-81.

17.Krzyżostaniak J, Surdacka A, Kulczyk T, Dyszkiewicz-Konwińska M, Owecka M (2014): Diagnostic accuracy of cone beam computed tomography compared with intraoral radiography for the detection of noncavitated occlusal carious lesions. Caries Res., 48(5):461466.

18.Şenel B, Kamburoğlu K, Üçok Ö, Yüksel S, Özen T, Avsever H (2010): Diagnostic accuracy of different imaging modalities in detection of proximal caries. Dentomaxillofacial Radiol., 39(8):501-511.

19.Tsuchida R, Araki K, Okano T (2007): Evaluation of a limited cone-beam volumetric imaging system: comparison with film radiography in detecting incipient proximal caries. Oral Surg Oral Med Oral Pathol Oral Radiol Endod., 104(3):412-416.

20.Valizadeh S, Tavakkoli MA, Vasigh HK, Azizi Z, Zarrabian T (2012): Evaluation of cone beam computed tomography (CBCT) system: comparison with intraoral periapical radiography in proximal caries detection. J Dent Res Dent Clin Dent., 6(1):1-7.

21.Rathore S, Tyndall D, Wright J, Everett E (2012): Ex vivo comparison of Galileos cone beam CT and intraoral radiographs in detecting occlusal 
caries. Dentomaxillofacial Radiol., 41(6):489-493.

22.Kalathingal SM, Mol A, Tyndall DA, Caplan DJ, Hill C (2007): In vitro assessment of cone beam local computed tomography for proximal caries detection. Oral Surg Oral Med Oral Pathol Oral Radiol Endod., 104(5):699-704.

23.Kamburoğlu K, Kurt H, Kolsuz E, Öztaș B, Tatar I, Çelik HH (2011): Occlusal caries depth measurements obtained by five different imaging modalities. Journal of digital imaging, 24(5):804813.

24.Kamburoğlu K, Murat S, Yüksel SP, Cebeci ARÍ, Paksoy CS (2010): Occlusal caries detection by using a cone-beam CT with different voxel resolutions and a digital intraoral sensor. Oral Surg Oral Med Oral Pathol Oral Radiol Endod., 109(5):e63-e69.

25.Sansare K, Singh D, Sontakke S, Karjodkar F, Saxena V, Frydenberg M et al. (2014): Should cavitation in proximal surfaces be reported in cone beam computed tomography examination? Caries Res., 48(3):208213.
26.Sansare K, Singh D, Sontakke S, Karjodkar F, Saxena V, Frydenberg M et al. (2014): Should cavitation in proximal surfaces be reported in cone beam computed tomography examination? Caries Res., 48(3):208213.

27.Qu X, Li G, Zhang Z, Ma X (2011): Detection accuracy of in vitro approximal caries by cone beam computed tomography images. Eur J Radiol., 79(2):e24-27.

28.Sousa Melo SL, Belem MDF, Prieto LT, Tabchoury CPM, Haiter-Neto F (2017): Comparison of cone beam computed tomography and digital intraoral radiography performance in the detection of artificially induced recurrent caries-like lesions. Oral Surg Oral Med Oral Pathol Oral Radiol Endod., 124(3):306-314.

29.Krzyzostaniak J, Kulczyk T, Czarnecka B, Surdacka A (2015): A comparative study of the diagnostic accuracy of cone beam computed tomography and intraoral radiographic modalities for the detection of noncavitated caries. Clin Oral Investig, 19(3):667-672.

30.Cheng JG, Zhang ZL, Wang XY, Zhang ZY, Ma XC, Li G (2012): Detection accuracy of proximal caries by phosphor plate and cone-beam computerized tomography images scanned with different resolutions. Clin Oral Investig, 16(4):1015-1021.

31.Kamburoglu K, Murat S, Yuksel SP, Cebeci AR, Paksoy CS (2010): Occlusal caries detection by using a cone-beam CT with different voxel resolutions and a digital intraoral sensor. Oral Surg Oral Med Oral Pathol Oral Radiol Endod, 109(5):e63-69. 